\title{
TRACING OF THE STREAM FLOWING THROUGH THE CAVE FERRANOVA BUŽA, CENTRAL SLOVENIA
}

\author{
SLEDENJE POTOKA V JAMI FERRANOVA BUŽA \\ NAD VRHNIKO
}

\author{
Miha STAUT ${ }^{1} \&$ Primož AUERSPERGER ${ }^{2}$
}

\begin{abstract}
UDC 556.34.04

Miha Staut \& Primož Auersperger: Tracing of the stream flowing through the cave Ferranova buža, central Slovenia

The article discusses the characteristics of the recently discovered ground water stream in the cave Ferranova buža and its possible karstic hydrological system. Its upstream connections have been narrowed to few possible springs by means of logical exclusion and have yet to be confirmed. For the purpose of establishing its linkage to the downstream springs around Vrhnika a water tracing experiment has been performed. Uranine was used as a tracer and sampled in intervals of eight hours at Primc's spring, Bečkaj's spring and Kožuh's spring. The connection was proved in all three observation points, with Kožuh's spring draining the largest quantity of the tracer. The tracer experiment evidenced that the dye was completely flushed downward in single transition curve almost without any retention.
\end{abstract} Keywords: karst, hydrology, water tracing, fluoresceine sodium.
Izvleček

UDK 556.34.04

Miha Staut \& Primož Auersperger: Sledenje potoka $v$ jami Ferranova buža nad Vrhniko

Prispevek obravnava značilnosti nedavno odkritega podzemnega vodotoka v jami Ferranova buža in njegovega kraškega hidrološkega sistema. Njegove gorvodne povezave so bile zožene na nekaj možnih virov s pomočjo logičnega izločanja. Za potrebe dognanja povezav $\mathrm{z}$ dolvodnimi izviri okrog Vrhnike, je bil izveden sledilni poskus. Uporabljeno sledilo je bilo uranin $\mathrm{z}$ intervalom vzorčenja na osem ur v Primcovem, Bečkajevem in Kožuhovem izviru. Povezava je bila dokazana z vsemi tremi izviri, vendar se je največja količina sledila pojavila v Kožuhovem izviru. Glede na rezultate sledenja je moč zaključiti, da se je uranin prenesel $\mathrm{v}$ enkratnem homogenem valu in da obstaja majhna verjetnost, da se je kje zadržal dlje.

Ključne besede: kras, hidrologija, vodno sledenje, uranin.

\section{INTRODUCTION}

If a caver asked us what is Ferranova buža like, despite probable sighs from the caving colleagues we would answer him, it is a thankful cave. It is not the intention to delve here into the relation that gradually establishes between the cave and its explorer(s). That relation is undoubtedly something special and needs a separate investigation, but would among karstologists probably sound too "personal" and thus un-scientific. The intention is to emphasize that after all the efforts put into it, it always knew how to return the favour with new and new surprising discoveries and in that way filled the game with satisfaction that lasts for already more that four years. It presented us with one of those gifts after one of our club's meetings when we decided to trace the stream disappearing in the terminal siphon of the cave. With the aid of some pretty rudimentary techniques we managed to achieve at first glance high quality results.

${ }^{1}$ Jamarski klub Železničar, Hrvatski trg 2, 1000, Ljubljana, e-mail: mihastaut@yahoo.co.uk

${ }^{2}$ JP Vodovod-Kanalizacija d.o.o., Vodovodna cesta 90, Ljubljana, e-mail: pauersperger@vo-ka.si

Received/Prejeto:14.09.2006 


\section{GENERAL GEOLOGICAL AND HYDROLOGICAL DESCRIPTION}

The entrance to Ferranova buža is located about 900 metres eastwards from the summit of Ulovka on the elevation $660 \mathrm{~m}$ above sea level (a.s.l.). After Buser (1968), Ulovka is structured by the Zaplanina nappe, where the upper Triassic dolomites are over-thrusted on the Cretaceous and Jurassic limestones of Logatec-Cerknica block. Limestones outcrop only southwards from the valley of Bela and in a narrow strip between Sveta trojica and Ulovka. The surface of the Ulovka massif is therefore dominated by a weakly expressed karstic morphology with a low drainage density and rare dolines.

The upper part of Ferranova buža evolved in the dolomite along one of the regional faults crossing the Ulovka massif in a dinaric direction. On the depth of 160 $\mathrm{m}$, where the cave significantly widens it passes into the limestone which can be traced down to the current bottom at $306 \mathrm{~m}$ a.s.l. The narrow upper part of the cave here actually joins a gallery of a completely different character with an active flow that in the direction about $100^{\circ}$ passes by (Fig. 1 and Fig. 2). In this second wider part the cave evolved along one or more bedding planes dipping southwards initially under the angle of $40^{\circ}$ but towards the bottom steepen up to $70^{\circ}$. With regard to the proximity of the Jurassic limestones it may be deducted that the cave crosses the Zaplanina nappe structure on the junction of the upper and the lower part of the cave. In that respect the cave would be one of the rare known cases of such crossings in Slovenia. showed contamination with faecal bacteria, evidencing that the cave stream is not the consequence of gathering of percolating water through the dolomite, such as in the case of the springs Lintvern and Staje (Habič, 1976). These two spring from dolomite about $1 \mathrm{~km}$ south-westwards from the entrance of the cave and were used for the Vrhnika's water supply.

Following the allogenic assumption, the map of sinking streams from Rovte hills (Fig. 2), that were predominantly traced into Kožuh's, Primc's and Bečkaj’s springs in Vrhnika (Bauer et al., 1976; Habič, 1976; Habič, 1996), indicates possible origins of the water in the cave. The plan of the cave in Fig. 2 overlaps to some extent with the upper reaches of the stream Korita and is therefore difficult to spot. Accounting for the elevation and with regard to the results of extensive water tracing experiments in the catchment of the Ljubljanica river (Bauer et al., 1976), ponors on the Planinsko polje can be excluded as possible sources of the water in the cave as the stream appears in the cave exactly on $500 \mathrm{~m}$ a.s.l. (metres above sea level). The same is true for the Logaščica sinking at about $450 \mathrm{~m}$ a.s.l. as well as the Petkovščica. The later flows into Loška jama with its bottom reaching below the critical depth. The Hotenjka, the Močilka, the Hlevišarka and the Žejska voda were at large traced towards Podroteja and Divje jezero. For the purpose of the Hotenjka tracing the Kožuh spring was sampled for the first time. Due to its too deep sinking cave it can be excluded similarly

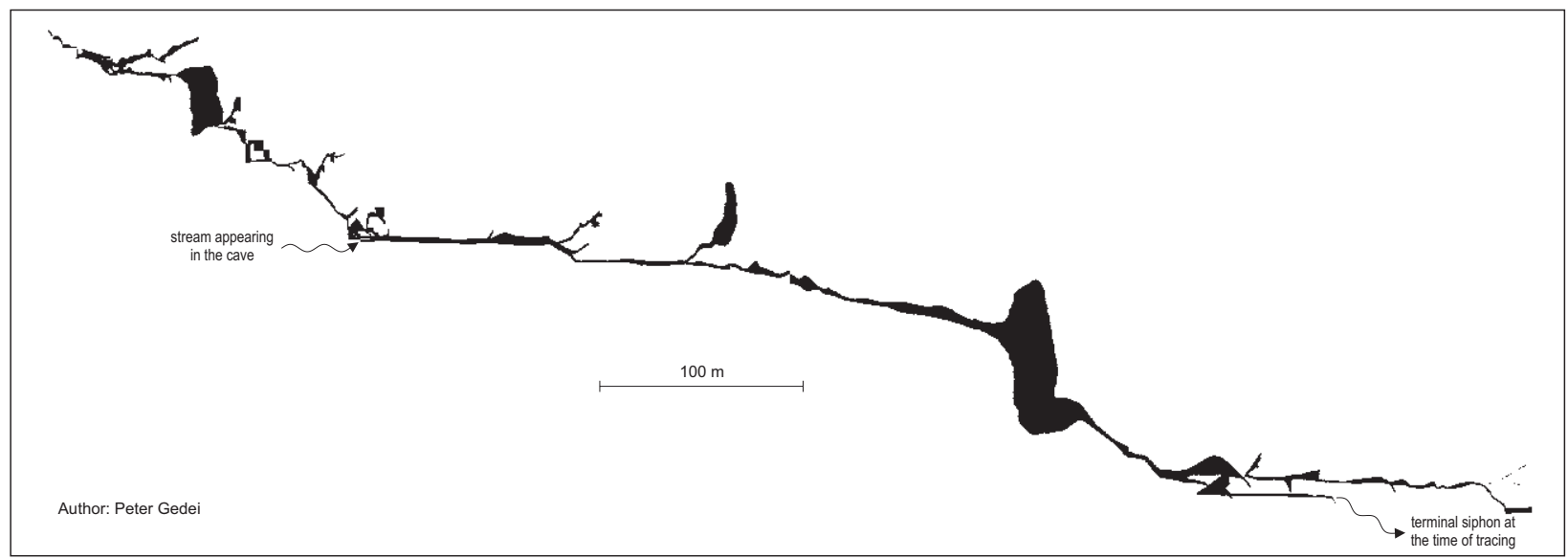

Fig. 1: Elevation of Ferranova buža.

This is why the possible source of the cave stream has to be traced in the same hydrogeological unit and not in the dolomite aquifer of Ulovka. This assumption can be confirmed by sandstone and chert pebbles found in the bed of the river showing its probable allogenic character. Additionally bacteriological analyses of the water as the others. Even the nearest stream the Korita sinks much too low for a possible connection with the upper siphon of the stream in Ferranova buža. With regard to its connection with Primc's and Kožuh's spring (Habič, 1996) it can be deduced that water from the Korita joins the stream from Ferranova buža somewhere below the 


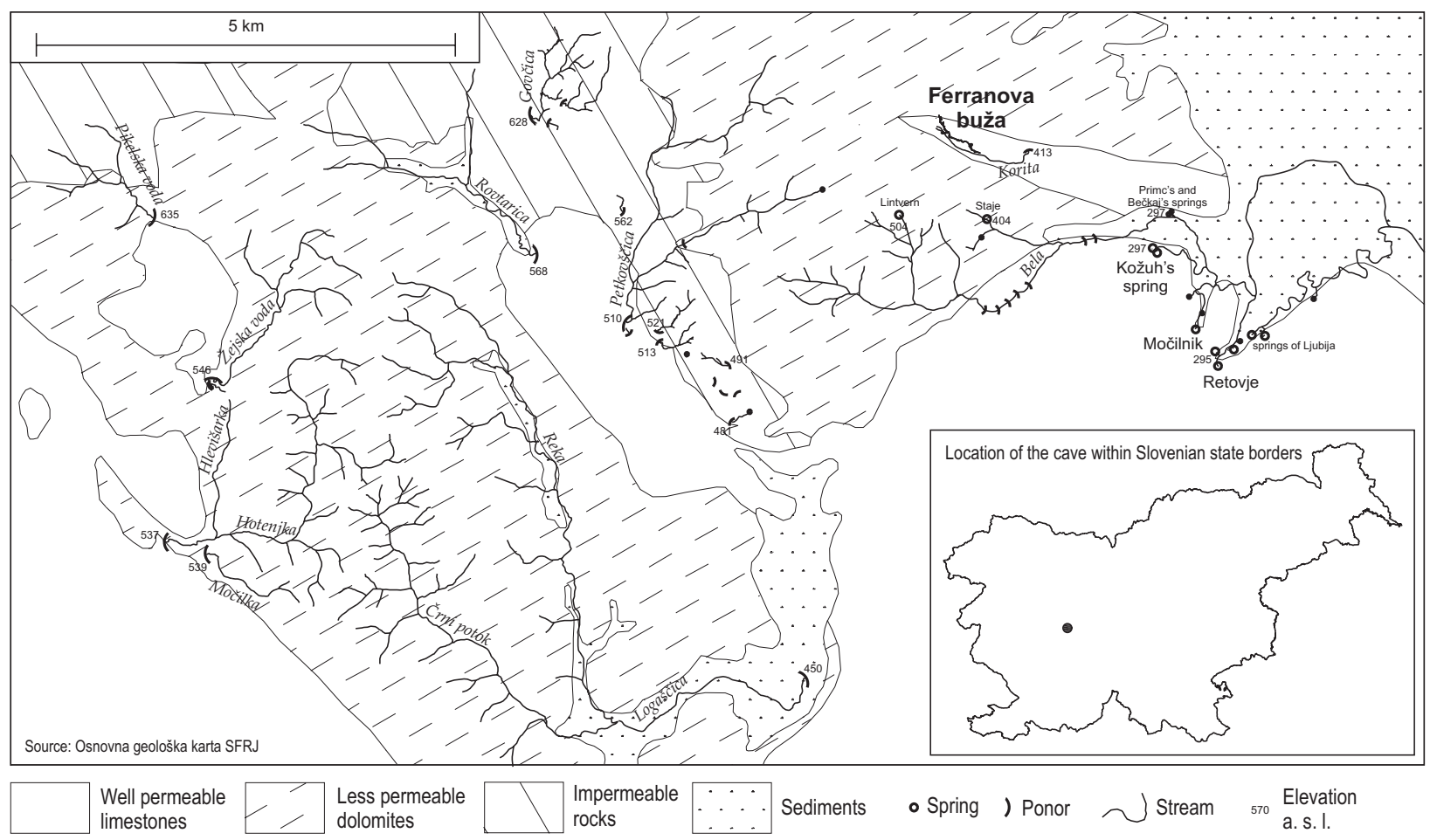

Fig. 2: Sinking streams in Rovte hills.

terminal siphon. By means of logical exclusion it can be established only the Rovtarica, the Govčica and the Pikelska voda sink high enough to be possible sources of the groundwater stream in Ferranova buža.

Fig. 3 shows possible upstream and established downstream water connections of Ferranova buža. It can be seen that the stream in the cave loses the largest part of its initial potential energy. From the elevation of 500 $\mathrm{m}$ a.s.l. the stream in only $500 \mathrm{~m}$ of horizontal distance falls to the elevation of $306 \mathrm{~m}$ a.s.l. The Ljubljana Moor around Vrhnika lies between 290 and 293 m a.s.l. while all three springs with established connections from Ferranova buža are located at $293 \mathrm{~m}$ a.s.l. The lowest part of the cave is separated from the corresponding downstream springs by $13 \mathrm{~m}$ of vertical and almost $2400 \mathrm{~m}$ of horizontal distance. The speleogenetic setting where the cave evolved thus enabled the stream to lose abruptly height. The characteristics of this change can at the moment only be guessed as upstream and downstream from the known parts the character of the cave is not known.

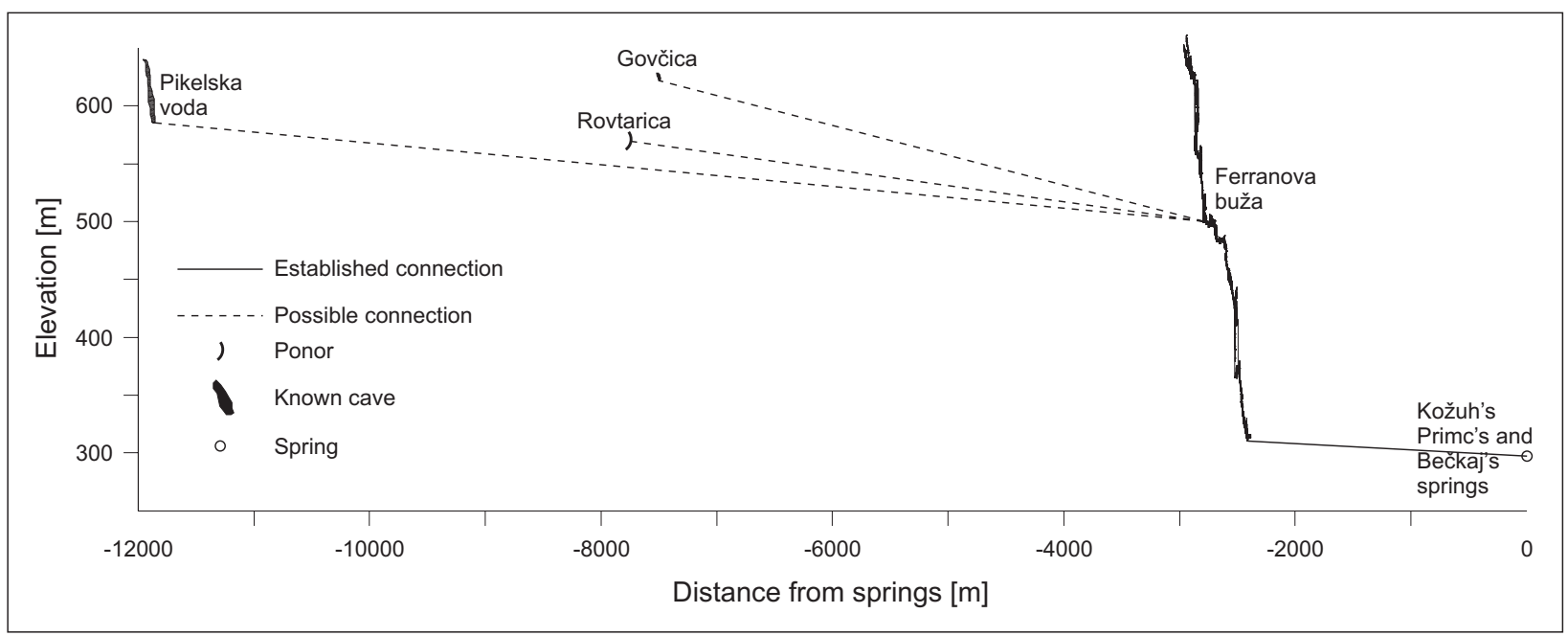

Fig. 3: Possible upstream and established downstream connections of Ferranova buža. 


\section{TRACING}

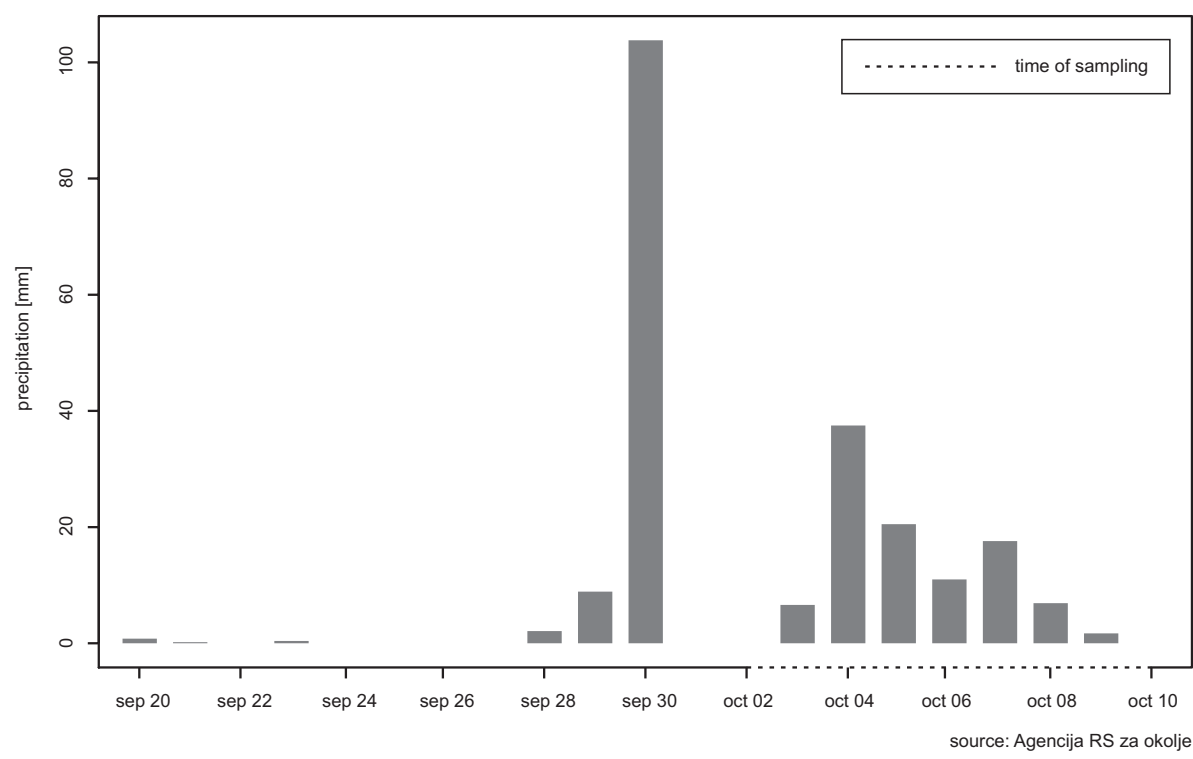

Fig. 4: Precipitation at the time of the tracing and immediately before it (precipitation station Rovte).

For the uranine determination the fluorescent spectrometry was used. Water samples were analysed with the instrument RF 1501 from Shimadzu, Kyoto, Japan. The analytical method has an accredited status according to SIST EN ISO/IEC 17025 (certificate No. LP-023). Duplicate samples were taken to test the precision in sampling and to control possible cross-contamination. For background evaluation water samples were collected before the tracing experiment at all relevant sampling points Primc's, Bečkaj's and Kožuh's spring as well as at the uranine injection point. After the uranine transition the sampling procedure continued until similar background values as before the tracing experiment were observed. From that data, the background changes during the tracer experiment were calculated by means of linear interpolation. Because of a relatively high sampling frequency and an appropriate sampling period after the uranine transition we could conclude that almost all uranine has passed the sampling points.

The discharges on all mentioned locations were estimated by means of a float let down the stream (Shaw, 1994). In that way the volumetric exchange of water in a unit of time on a specified transect can be estimated. On each transect the measurement was repeated three times and the average was calculated. The method is more suitable for small discharges and not very turbulent flows. Its advantages over more elaborate and accurate methods are the inexpensive and volume saving tool set needed for the completion of the measurement. With two hours of restrictive and mind boggling passages, it appears to be the winning method.

Uranine (as $5.0 \mathrm{~g} / \mathrm{L}$ solution, $50 \mathrm{~g}$ of uranine total) was injected on $2^{\text {nd }}$ October 2005 at 16:30 into the stream, which flows through Ferranova buža, at the site called Tartar. At the time of the sampling, this was the lowest known point of Ferranova buža immediately before the siphon. The springs were sampled 8 days on 8 hours intervals.

At the time of the tracing experiment and immediately before it there were two significant precipitation events associated with passing of weather fronts over Slovenia (Markošek, 2005a; Markošek, 2005b). They can be identified in the peaks of the measurements at the precipitation station Rovte (Fig. 4) and Vrhnika (not shown), but the later having about $20 \%$ lower precipitation. On $2^{\text {nd }}$ October 2005 the discharge in the cave was estimated to be low. The measurement indicated $11 \mathrm{l} / \mathrm{s}$. After both precipitation events the discharges of sampled springs significantly increased. According to the sampling diary of one of the samplery the water levels of two smaller springs (Primc's and Bečkaj's) during the sampling period did not vary a lot. $8^{\text {th }}$ October the discharges were 62 l/s and 73 l/s respectively. On the other hand Kožuh's spring with a magnitude larger discharge (on the same day as the previous two it was estimated at $1975 \mathrm{l} / \mathrm{s}$ ) varied a lot during the experiment. The same diary clearly reflected the two precipitation events. On $1^{\text {st }}$ October the lowest water level was recorded and it has increased until $4^{\text {th }}$ October at 6:00 am. The next day it fell for about $20 \mathrm{~cm}$ but from $6^{\text {th }}$ to $9^{\text {th }}$ October again started to rise never reaching the first height. After that it levelled off. This narration indicates that the water pulse from Rovte hills employs about four days to reach the springs around Vrhnika. 


\section{RESULTS OF THE TRACING EXPERIMENT}

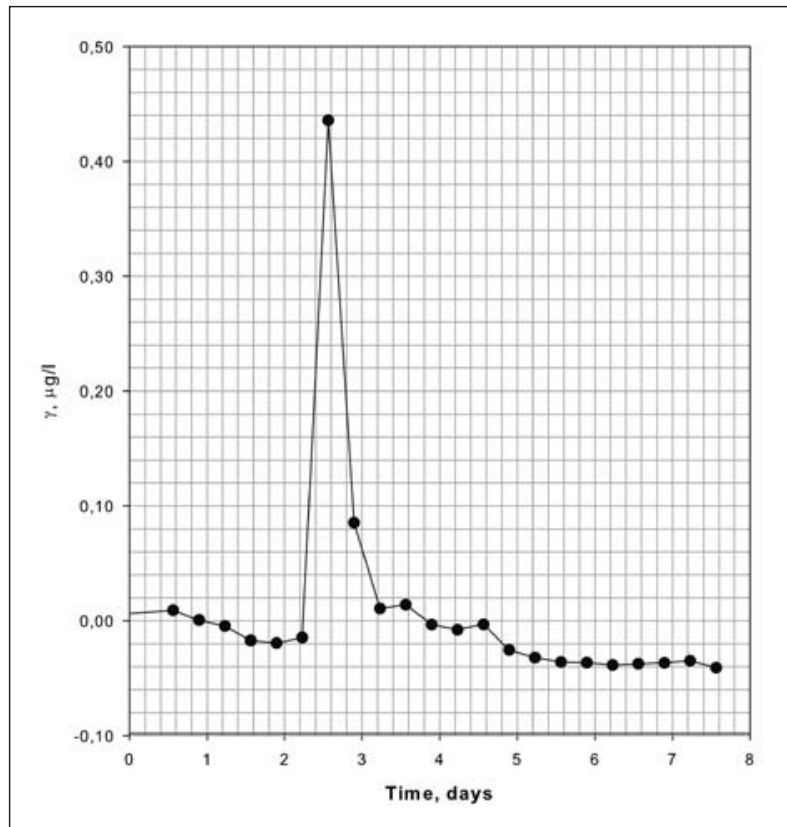

Fig. 5: Concentration of uranine at the Kožuh's spring without subtractions of the background.

At Kožuh's spring we detected uranine on $4^{\text {th }}$ October 2005 at 22:00, 53.5 hours after the injection. The maximum concentration was registered on $5^{\text {th }}$ October 2005 at 06:00 a.m., 61.5 hours after the injection. The last traces of uranine were detected on $9^{\text {th }}$ October 2005 at 22:00 p.m., 173.5 hours after the injection.

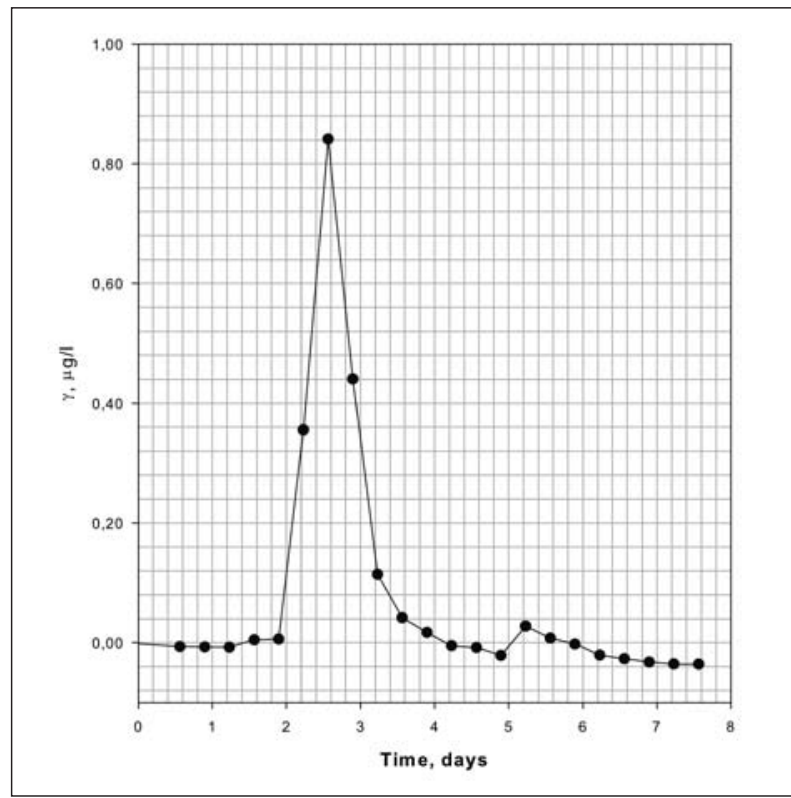

Fig. 7: Concentration of uranine at the Primc's spring without subtractions of the background.

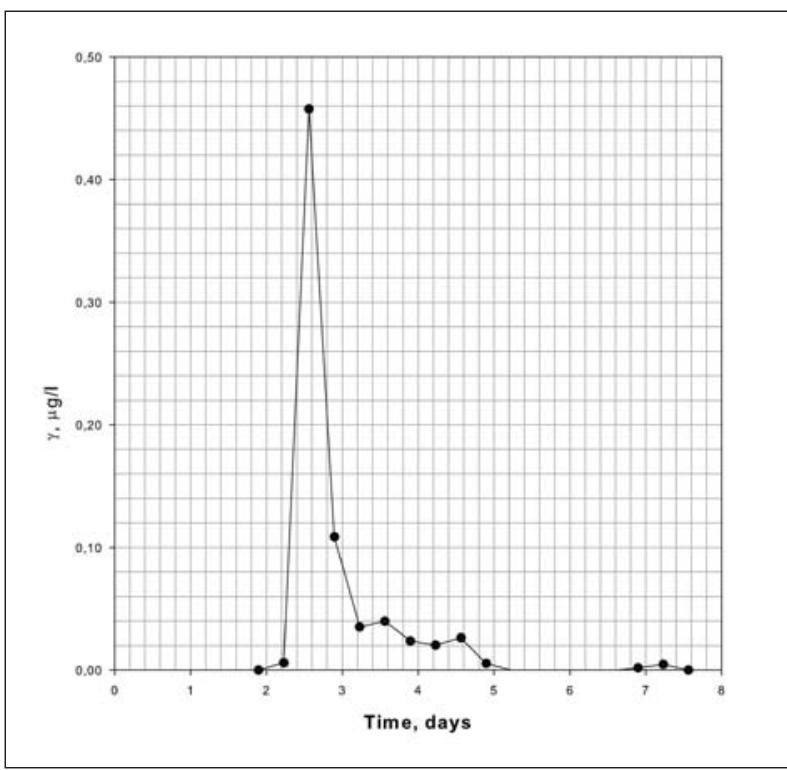

Fig. 6: Concentration of uranine at the Kožuh's spring with subtracted background.

At the Primc's spring we detected uranine on $4^{\text {th }}$ October 2005 at 6:00 a.m., 37.5 hours after the injection. The maximum concentration was on $5^{\text {th }}$ October 2005 at 6:00 a.m., 61.5 hours after the injection. The last traces of uranine were detected on $9^{\text {th }}$ October 2005 at 6:00, 157.5 hours after the injection.

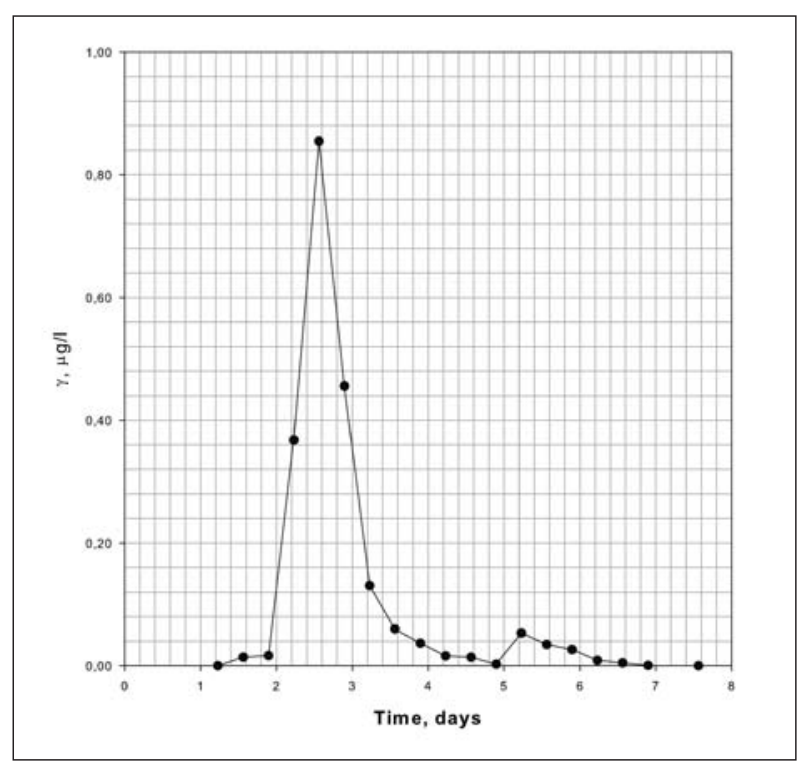

Fig. 8: Concentration of uranine at the Primc's spring with subtractions of the background. 


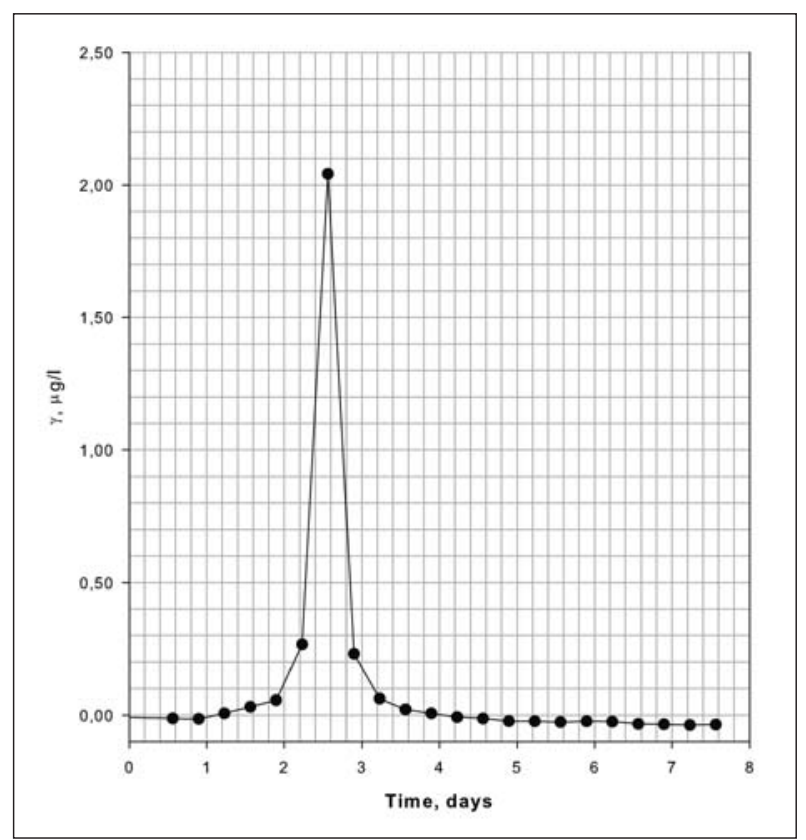

Fig. 9: Concentration of uranine at the Bečkaj's spring without subtractions of the background.

At the Bečkaj's spring we detected uranine on $3^{\text {rd }}$ October 2005 at 22:00 p.m. in 29.5 hours after the injection. The maximum concentration was recorded on $5^{\text {th }}$ October 2005 at 6:00 a.m., 61.5 hours after the injection. The last traces of uranine were detected on $8^{\text {th }}$ October 2005 at 22:00 p.m., 149.5 hours after the injection.

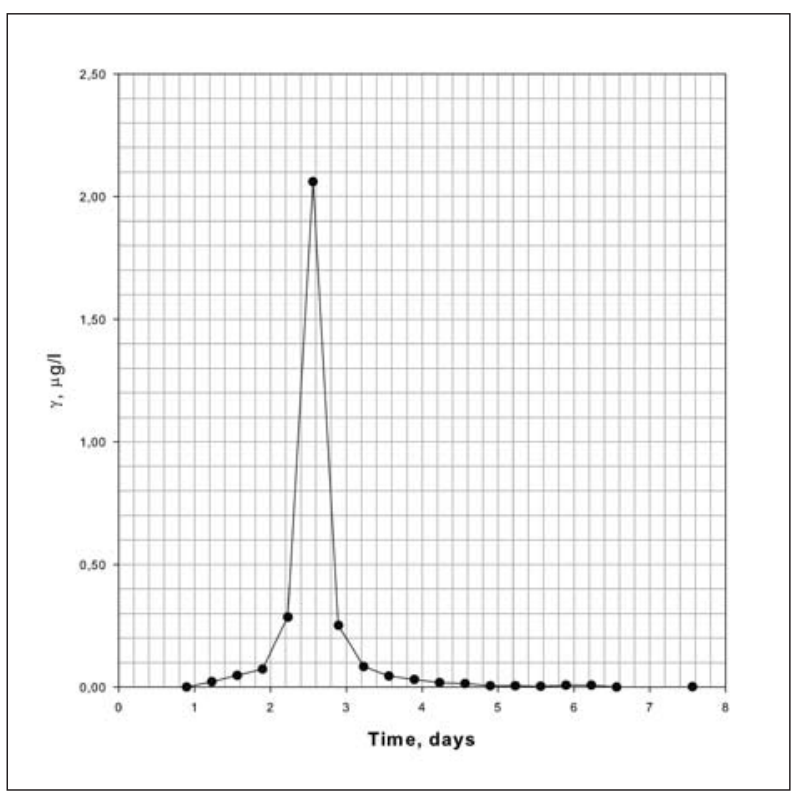

Fig. 10: Concentration of uranine at the Bečkaj's spring with subtractions of the background.

In Table 1, there is a recovery calculation for the injected uranine. The calculation has been performed from the flow data and transition curves for uranine.

Tab. 1: Experimentally determined distribution of uranine across the sampling points and the recovery calculation. $\Phi-w a t e r$ flow, $\gamma$ - mass concentration, $A$ - area. $m$ (injected) $=50.0 \mathrm{~g}$.

\begin{tabular}{|l|c|c|c|c|c|}
\hline \multicolumn{1}{|c|}{ Sampling site } & $\begin{array}{c}\gamma \text { (maximum) } \\
{[\mu \mathrm{g} / \mathrm{l}]}\end{array}$ & $\begin{array}{c}\mathrm{A} \text { (transition } \\
\text { curve) }[\mu \mathrm{g} / \mathrm{l} \times \text { day }]\end{array}$ & $\begin{array}{c}\Phi \\
{[\mathrm{l} / \mathrm{s}]}\end{array}$ & $\mathrm{m}$ (uranine) $[\mathrm{g}]$ & $\begin{array}{c}\text { Relative quantity } \\
\text { of uranine } \\
\text { determined at } \\
\text { sampling site [\%] }\end{array}$ \\
\hline Kožuh's spring & 0.46 & 0.2347 & 1975 & 40.05 & 80.7 \\
\hline Primc's spring & 0.85 & 0.6312 & 62 & 3.38 & 6.8 \\
\hline Bečkaj's spring & 2.10 & 0.9822 & 73 & 6.18 & 12.5 \\
\hline Total & - & - & 2110 & 49.60 & 100.0 \\
\hline
\end{tabular}

\section{DISCUSSION}

From the collected evidence, it appears that a part of waters flowing from Rovte hills towards the catchment of Ljubljanica river flow through Ferranova buža. By analysing the geological characteristics of the area where Ferranova buža has developed and some characteristics of its groundwater stream (bacteriological analysis and riv- er sediment characteristics), it is possible to determine its allogenic source. Additionally supported by the extensive water tracing experiments in the seventies (Bauer et al., 1976) the source can be confined to Rovte hills between Ljubjana Moor and Hotederščica valley. A comparison of the elevation of sinks in Rovte hills and known caves 
behind them with the elevation where the stream in the cave first appears leads to the logical exclusion of some possible candidates remaining with only three options.

The results of the water tracing experiment indicated the recovery of $99.2 \%$ of the injected uranine. This relatively surprising accuracy could be explained by a fast transport of uranine, without any retardation. The recovery calculation mainly depends on the flow changes, which are connected with the weather conditions at the time of experiment and hydrodynamic conditions of the aquifer before and during the experiment. We presume that the influence of changes in weather conditions at the week of the tracing experiment was relatively weak. This could be explained by an approximate four days shift between precipitation events and significant changes in water flows.

The tracing experiment of the cave stream towards the three springs at the entrance to the valley of Bela proved the connections with all of them. The tracer first appeared in Bečkaj's spring ( $29.5 \mathrm{~h}$ ) with the velocity of $2.3 \mathrm{~cm} / \mathrm{s}$. Eight hours later with the velocity of $1.8 \mathrm{~cm} / \mathrm{s}$, the tracer was confirmed in Primc's spring as well. As the two are only $50 \mathrm{~m}$ apart, the time lag confirms Habič hypothesis, which presumes that the channels towards the two springs separate a certain distance from them (Habič, 1996). At the latest, after $53.5 \mathrm{~h}$, the uranine was transported with the velocity of $1.1 \mathrm{~cm} / \mathrm{s}$ to Kožuh's spring feeding the Hrib's brook. Despite linear distances from the terminal siphon in the cave with to springs show very small differences, the tracer required a much greater time to the third one. Contrary to the first two it is situated on the southern flank of the valley. This indicates the possibility that the channel leading to it, first feeds the smaller two and only afterwards passes below the sediments of the Bela valley to finally spring in it. In all of the sampled springs however peak tracer concentrations were measured 61.5 hours after the injection. Despite slower connections and lower concentrations of the tracer in the Kožuh's spring, about $80 \%$ off all the tracer appeared in it. This again indicated the main role of the Kožuh's spring as a collector of ground water drained from Rovte hills in the Ljubljanica catchment.

\section{ACKNOWLEDGEMENT}

We wish to thank the company JP Vodovod-Kanalizacija d.o.o. for support of this study.
We thank Andrej Stržinar and Marko Krašovec for unselfish help with time-consuming sampling in the week of the experiment.

\section{REFERENCES}

Bauer, F., Gospodarič, R., Habič, P., 1976: Underground water tracing : investigations in Slovenia 1972-1975.- Institute for Karst Research SAZU, p. 309, Postojna.

Buser, S., 1965: Geološka zgradba južnega dela Ljubljanskega barja in njegovega obrobja.- Geologija, 8, 34-57, Ljubljana.

Ferran, M., 2003: Ferranova buža.- Bilten Jamarskega kluba Železničar, 23, 7-13, Ljubljana.

Ferran, M., 2006: Ferranova buža - ponovno.- Bilten Jamarskega kluba Železničar, 25, 9-17, Ljubljana.

Ferran, M., 2006: Pucov brezen.- Bilten Jamarskega kluba Železničar, 25, 18-25, Ljubljana.

Habič, P., 1976: Hidrogeološke značilnosti povodja Bele pri Vrhniki in problemi izrabe kraških voda za oskrbo.- Acta carsologica, 7, 215-256, Ljubljana.
Habič, P., 1996: Vrhniški izviri in njihovo kraško zaledje. Vrhniški razgledi, 1, 43-74, Vrhnika.

Käss, W., 1998: Tracing Technique in Geohydrology.- A.A. Balkema, p. 581, Roterdam/Brookfield.

Markošek, J., 2005a: Razvoj vremena v septembru 2005.Mesečni bilten, 12, 9, 20-25, Ljubljana.

Markošek, J., 2005b: Razvoj vremena v oktobru 2005.- Mesečni bilten, 12, 10, 21-26, Ljubljana.

Shaw, E. M., 1994: Hydrology in Practice.- Chapman \& Hall, p. 569 , London. 
